\begin{tabular}{|c|c|}
\hline Title & Fluorination of alcohols and diols with a novel fluorous deoxy-fluorination reagent \\
\hline Author(s) & Furuya, Tsukasa; Nomoto, Takashi; Fukuhara, T suyoshi; Hara, Shoji \\
\hline Citation & $\begin{array}{l}\text { Journal of Fluorine Chemistry, 130(3), 348.353 } \\
\text { https://doi.org/10.1016 J.jfluchem.2008.12.010 }\end{array}$ \\
\hline Issue Date & 2009-03 \\
\hline DOC URL & http:/hdl.handle.net/2115/36636 \\
\hline Type & article (author version) \\
\hline File Information & hara 109.pdf \\
\hline
\end{tabular}

Instructions for use 


\section{Fluorination of alcohols and diols with a novel fluorous deoxy-fluorination reagent}

Tsukasa Furuya, Takashi Nomoto, Tsuyoshi Fukuhara, Shoji Hara*

Graduate School of Engineering, Hokkaido University, Sapporo 060-8628, Japan

Abstract We prepared a novel fluorous deoxy-fluorination reagent $N, N$-diethyl- $\alpha, \alpha$-difluoro-[3,5-bis(1H,1H,2H,2H-perfluorodecyl)benzyl]amine

from 3,5-diiodobenzoic acid $\quad$ (3b) via $N, N$-diethyl-3,5-bis( $1 H, 1 H, 2 H, 2 H$-perfluorodecyl)benzamide (2b) in four steps and used it for the fluorination of alcohols and diols. After the fluorination reactions, the isolation of the products and recovery of $\mathbf{2} \mathbf{b}$ was performed by extraction with a fluorous/organic solvent system.

Keywards: Fluorous fluorination reagent; Deoxy-fluorination reaction; $N, N$-Diethyl- $\alpha, \alpha$-difluoro-[3,5-bis $(1 H, 1 H, 2 H, 2 H$-perfluorodecyl)benzyl]amine

\section{Introduction}

Recently, fluorous chemistry using a fluorous/organic biphasic system has been developing as an environmentally friendly technology. The highly fluorinated compounds are selectively soluble in fluorocarbon solvents and separable from other organic compounds by simple extraction with a fluorous/organic biphasic solvent systems. Many fluorous reagents having fluorous tags have been prepared and 1

*Corresponding author. Fax: +81-11-706-6556

e-mail address: shara@eng.hokudai.ac.jp 
successfully applied to organic synthesis [1]. The deoxy-fluorination reaction is a useful method for the selective introduction of one or two fluorine atoms into molecules and many deoxy-fluorination reagents such as DAST and Deoxofluor have been developed and used [2]. However, to our knowledge, no recyclable fluorous deoxy-fluorination reagents have been reported so far. Recently we reported the fluorination of alcohols [3], aldehydes [4], diols [5], amino alcohols [6], and epoxides [7] using a novel deoxy-fluorination reagent, $N, N$-diethyl- $\alpha, \alpha$-difluoro-3-methylbenzylamine (DFMBA) 1a, which is prepared from $N, N$-diethyl-3-methylbenzamide 2a and returns to 2 a after the fluorination reaction. Therefore, we planned to prepare the fluorous deoxy-fluorination reagent, $N, N$-diethyl- $\alpha, \alpha$-difluoro-[3,5-bis( $1 H, 1 H, 2 H, 2 H$-perfluorodecyl)benzyl]amine $\mathbf{1 b}$, and apply it to the fluorination of alcohols. After the fluorination reaction, $\mathbf{1 b}$ will return to $\mathbf{2} \mathbf{b}$, and the recovery of $\mathbf{2} \mathbf{b}$ as well as isolation of products could be performed by simple extraction with a fluorous/organic solvent system [Scheme 1].

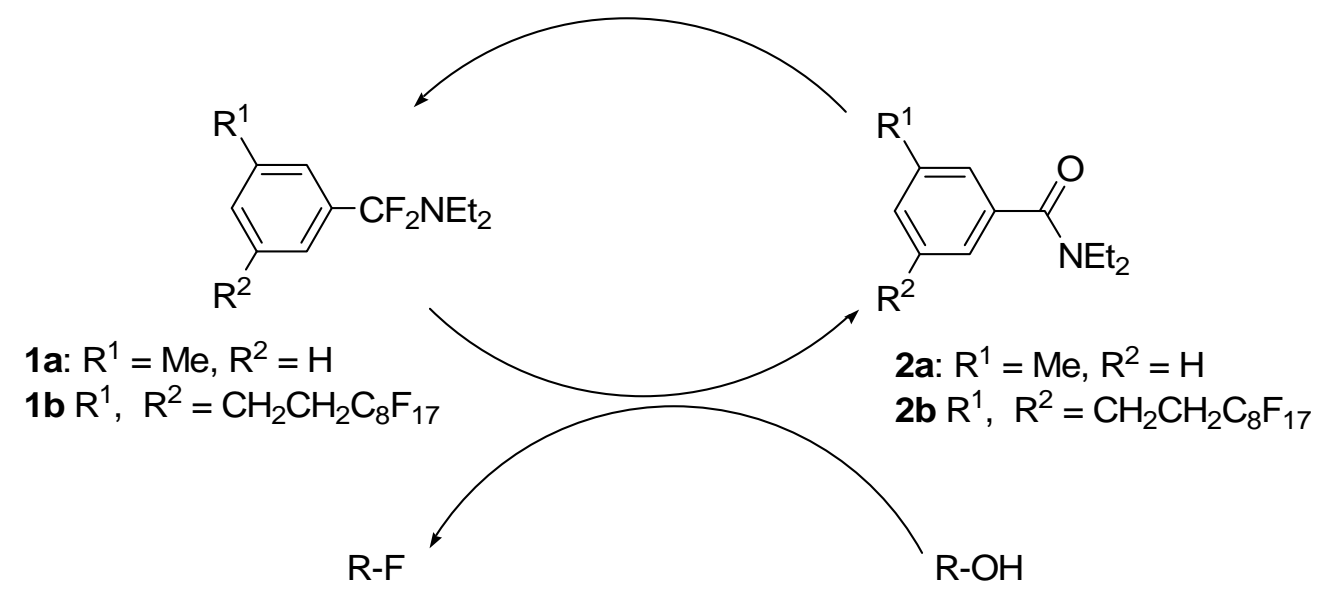

Scheme 1.

\section{Result and discussion}




\subsection{Preparation of fluorous fluorination reagent $\mathbf{1 b}$}

We prepared a fluorous deoxy-fluorination reagent, $N, N$-diethyl- $\alpha, \alpha$-difluoro-[3,5-bis( $1 H, 1 H, 2 H, 2 H$-perfluorodecyl)benzyl]amine $\mathbf{1 b}$, from 3,5-diiodobenzoic acid $\mathbf{3 b}$ [8] in four steps via $N, N$-diethyl-3,5-diiodobenzamide $\mathbf{4 b}$. Introduction of the fluorous tags was performed by a Heck-type reaction of $\mathbf{4 b}$ with 1H,1H,2H-perfluorodec-1-ene, followed by hydrogenation [9]. The resulting $N, N$-diethyl-3,5-bis $(1 H, 1 H, 2 H, 2 H$-perfluorodecyl)benzamide $\mathbf{2 b}$ was converted to $\mathbf{1 b}$ by deoxychlorination with oxalyl chloride, followed by a halogen-exchange reaction with $\mathrm{Et}_{3} \mathrm{~N}-3 \mathrm{HF}$ [10]. The fluorous fluorination reagent $\mathbf{1 b}$ is a moisture sensitive white solid and can be kept in a Teflon ${ }^{\mathrm{TM}}$ PFA bottle with a tight screw cap under inert atmosphere [Scheme 2].

$$
\begin{aligned}
& \text { 3b } \underset{\text { 2) } \mathrm{Et}_{2} \mathrm{NH}}{\stackrel{\text { 1) } \mathrm{SOCl}_{2}}{\longrightarrow}} \text { 4b } \underset{\mathrm{Bu}_{4} \mathrm{NBr}, \mathrm{AcONa}, \mathrm{DMF}}{\stackrel{\mathrm{CH}_{2}=\mathrm{CHC}_{8} \mathrm{~F}_{17} \mathrm{Pd}(\mathrm{OAc})_{2}}{\longrightarrow}} \mathbf{5 b} \\
& \underset{\text { AcOEt }}{\stackrel{\mathrm{H}_{2}, 10 \% \mathrm{Pd}-\mathrm{C}}{\longrightarrow}} \mathbf{2 b} \quad \frac{\text { 1) } \mathrm{COCl}_{2}}{\text { 2) } \mathrm{Et}_{3} \mathrm{~N}-3 \mathrm{HF}, \mathrm{Et}_{3} \mathrm{~N}} \mathbf{1 b}
\end{aligned}
$$
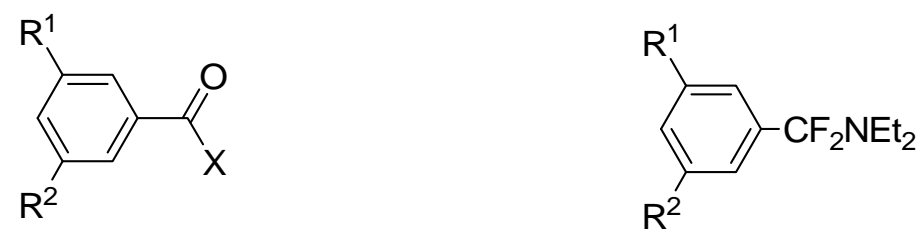

Scheme 2. 
2.2. Fluorination of alcohols with the fluorous deoxy-fluorination reagent $\mathbf{1 b}$ and the separation of products and recovery of $\mathbf{2} \boldsymbol{b}$ by extraction with a fluorous/organic solvent system

Initially, we examined the fluorination ability of $\mathbf{1 b}$ by applying it for the deoxy-fluorination of 1-dodecanol and butyl 5-hydroxypentanoate 6. The reactions were completed at $98{ }^{\circ} \mathrm{C}$ in $3 \mathrm{~h}$, and the corresponding fluorinated products, 1-fluorododecane and butyl 5-fluoropentanoate 7 , were obtained in $88 \%$ and $87 \%$ yields, respectively. These results indicated that the fluorination ability of $\mathbf{1 b}$ is comparable to that of DFMBA 1a [3], as shown in Table 1.

Table 1 Fluorination of alcohols with $\mathbf{1 a}$ or $\mathbf{1 b}^{\mathrm{a}}$

\begin{tabular}{|c|c|c|c|}
\hline \multirow{2}{*}{$\mathrm{R}-\mathrm{OH}$} & $1 \mathbf{a}$ or $\mathbf{1 b}$, heptane & \multirow{2}{*}{$R-F$} & \\
\hline & $98^{\circ} \mathrm{C}, 3 \mathrm{~h}$ & & \\
\hline Alcohol & Fluorination reagent & Product & Yield $(\%)^{b}$ \\
\hline $\mathrm{C}_{12} \mathrm{H}_{25}-\mathrm{OH}$ & $1 a$ & $\mathrm{C}_{12} \mathrm{H}_{25}-\mathrm{F}$ & $86^{c}$ \\
\hline $\mathrm{C}_{12} \mathrm{H}_{25}-\mathrm{OH}$ & $1 b$ & $\mathrm{C}_{12} \mathrm{H}_{25}-\mathrm{F}$ & 88 \\
\hline $\mathrm{BuOOC}\left(\mathrm{CH}_{2}\right)_{4}-\mathrm{OH}$ & $1 b$ & $\mathrm{BuOOC}\left(\mathrm{CH}_{2}\right)_{4}-\mathrm{F}$ & 87 \\
\hline 6 & & 7 & \\
\hline
\end{tabular}

a 1.2 eq of $1 \mathbf{a}$ or $\mathbf{1 b}$ to alcohol was used. ${ }^{\mathrm{b}}$ Isolateion yield based on alcohol used. ${ }^{\mathrm{c}}$ ref. 3.

To separate the product and the amide $\mathbf{2} \mathbf{b}$, their partition ratios in various fluorous and organic solvent systems were examined (Table 2). When FC-77 (a mixture of perfluoroalkanes and pefluorocyclic ethers) was used as the fluorous solvent, an appropriate organic solvent could not be found for their separations (Entries 1 and 2). However, better results were obtained with PFMC (perfluoromethylcyclohexane). When 
2b and the product were dissolved in a mixture of PFMC and toluene, the product came to the toluene phase exclusively ( $>99 \%$ ), and $\mathbf{2 b}$ was present in PFMC phase selectively $(89 \%)$ (Entry 3). For the separation of $\mathbf{2 b}$ and $\mathbf{7}$, the solvent system of FC-77 + HFE-7100 (nonafluorobutyl methyl ether)/ $\mathrm{CH}_{3} \mathrm{CN}\left(5 \% \mathrm{H}_{2} \mathrm{O}\right)$ was superior to the PFMC/toluene system. Thus, when $\mathbf{2 b}$ and $\mathbf{7}$ were dissolved in that solvent system, $\mathbf{2 b}$ came to the fluorous phase exclusively $(>99 \%)$, and 7 was predominantly present in the organic phase (97\%) (Entry 4).

Table 2 Fluorous organic liquid/liquid partition of amide (2b) and products

\begin{tabular}{lllll}
\hline \multirow{2}{*}{ Entry } & Solvent & \multicolumn{3}{c}{ Partition (fluorous : organic $)^{\mathrm{a}}$} \\
& & $\mathbf{2 b}$ & $\mathrm{C}_{12} \mathrm{H}_{25}-\mathrm{F}$ & $\mathbf{7}$ \\
\hline 1 & FC-77 : hexane $(2: 1)$ & $89: 11$ & $20: 80$ & $19: 81$ \\
2 & FC-77 : toluene $(2: 1)$ & $80: 20$ & $<1:>99$ & \\
3 & PFMC : toluene $(2: 1)$ & $89: 11$ & $<1:>99$ & $<1:>99$ \\
4 & FC-77+ HFE-7100: $\mathrm{CH}_{3} \mathrm{CN}\left(5 \% \mathrm{H}_{2} \mathrm{O}\right)(2: 1)^{\mathrm{b}}$ & $>99:<1$ & $38: 62$ & $3: 97$ \\
\hline
\end{tabular}

${ }^{a}$ Determined by GC. ${ }^{b}$ FC-77 : HFE-7100 $=1: 1$

After the reaction of 1-dodecanol with $\mathbf{1 b}$, the solvent was removed under reduced pressure and the residue was dissolved in the solvent system of PFMC/toluene $(2: 1)$. The separated toluene phase was washed with PFMC once and 1-fluorododecane was obtained in a $75 \%$ yield ( $>99 \%$ purity) from the toluene phase. On the other hand, GC analysis showed that the PFMC phase contains 2b, 1-fluorododecane and dodecyl 3,5-bis $(1 H, 1 H, 2 H, 2 H$-perfluorodecyl)benzoate 8 in a ratio of 87:7:6 (Scheme 3) [11]. Benzoate 8 was generated by the hydrolysis of the intermediate derived from 1-dodecanol and $\mathbf{1 b}$ [3], and found only in the PFMC phase. The recovered $\mathbf{2 b}$ and $\mathbf{8}$ can be converted to $\mathbf{1 b}$. 


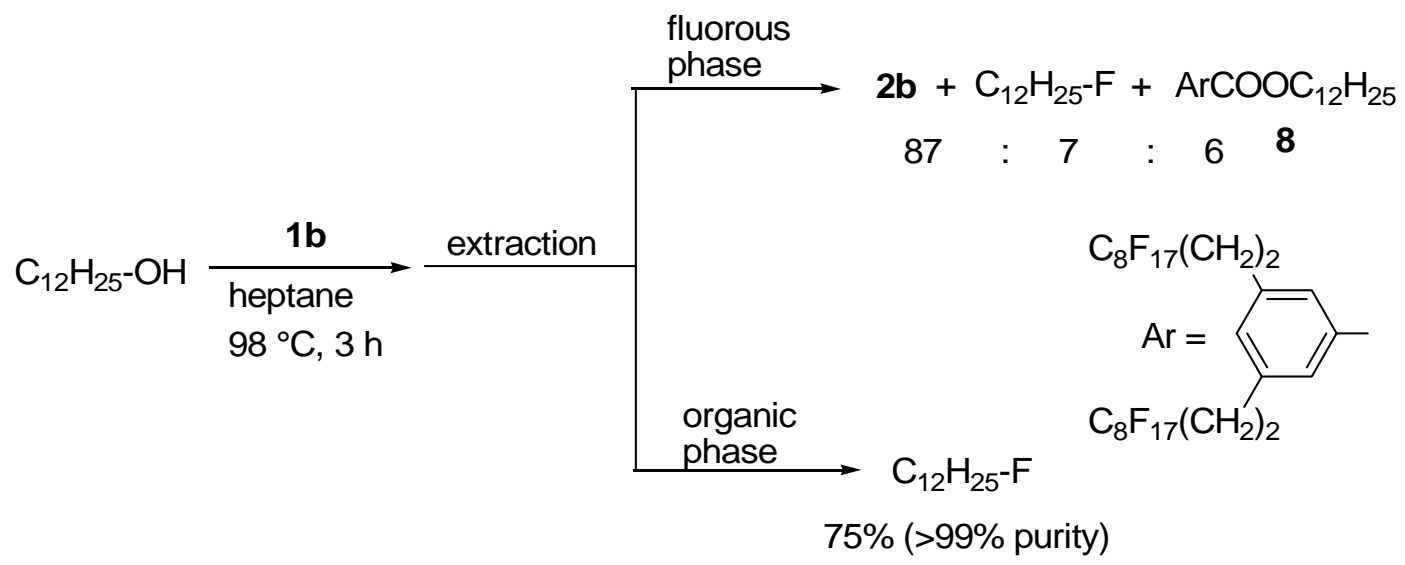

Scheme 3.

In the reaction of $\mathbf{6}$ with $\mathbf{1 b}$, the concentrated reaction mixture was dissolved in the solvent system of FC-77 and $\mathrm{HFE}-7100 / \mathrm{CH}_{3} \mathrm{CN}\left(5 \% \mathrm{H}_{2} \mathrm{O}\right)(2: 1)$. The separated organic layer was washed with a mixture of FC-77 and HFE-7100. From the organic phase, 7 was obtained in a $72 \%$ yield ( $>99 \%$ purity). In the fluorous phase, $2 \mathbf{b}, \mathbf{7}$, and 4-butoxycarbonylbutyl 3,5-bis $(1 H, 1 H, 2 H, 2 H$-perfluorodecyl)benzoate 9 were present in a ratio of 95:2:3 (Scheme 4).

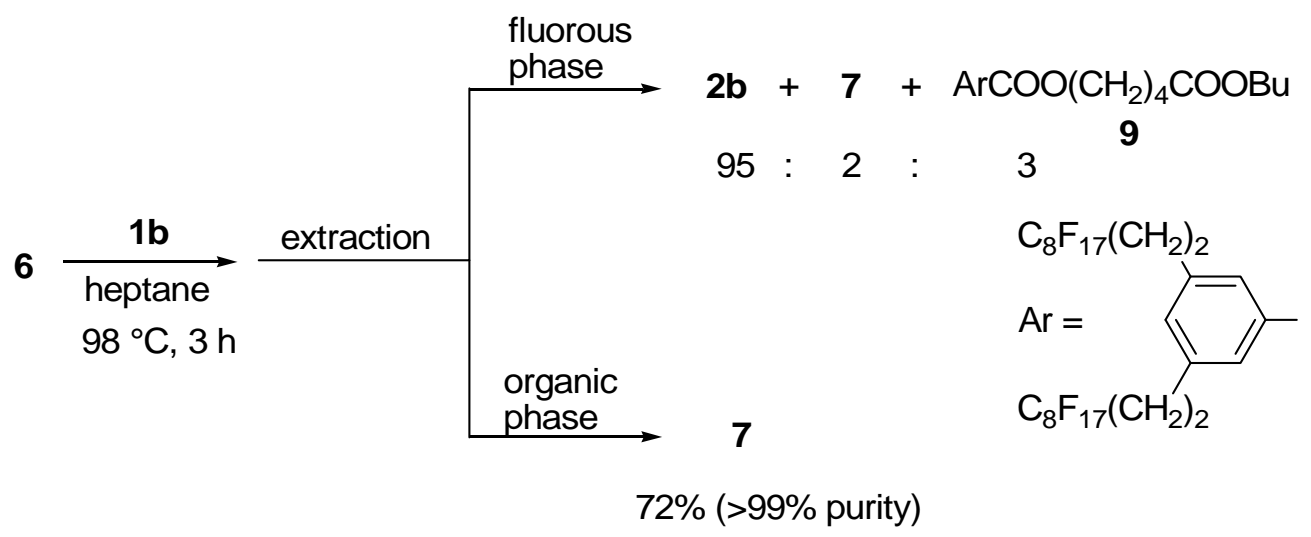

Scheme 4.

Thus, the fluorination of alcohols $\mathbf{3}$ and $\mathbf{6}$ can be achieved with $\mathbf{1 b}$, and separation of the 
fluorinated product and recovery of $\mathbf{2 b}$ and the ester $(\mathbf{8}$ or $\mathbf{9})$ are possible by simple extraction with a fluorous/organic solvent systems.

\subsection{Fluorination of diols with $\mathbf{1 b}$}

Next, we applied $\mathbf{1 b}$ for the fluorination of 1,2-diols. In the reaction of DFMBA with 1,2- or 1,3-diols, selective monofluorination occurred and 3-methylbenzoates of the corresponding fluorohydrins were formed [5]. The perfluoroalkylated benzoates of fluorohydrins, generated by the reaction of $\mathbf{1 b}$ with 1,2-diols, would be convertible to the corresponding fluorohydrins by transesterification. The separation of the generated fluorohydrins and recovery of the fluorous reagent would be possible by extraction with a fluorous/organic solvent system (Scheme 5).

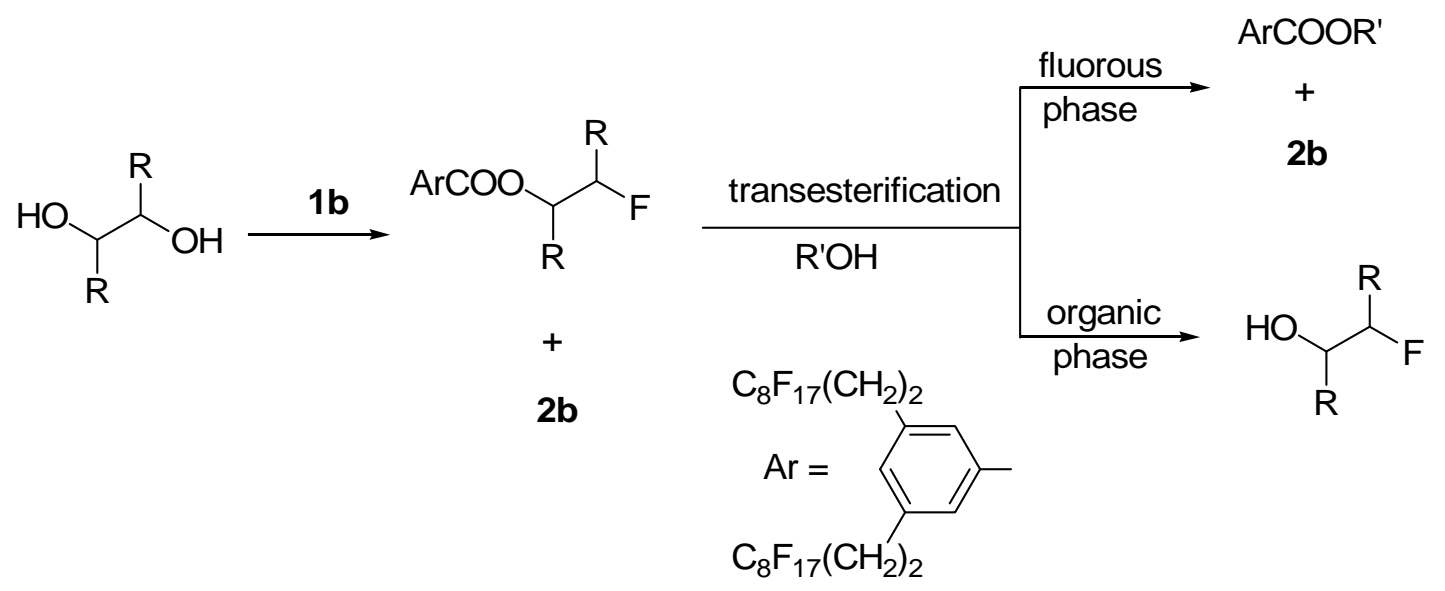

Scheme 5.

We performed the fluorination of ethylene glycol with 2.4 eq of $\mathbf{1 b}$ at $95{ }^{\circ} \mathrm{C}$ for $1 \mathrm{~h}$ and obtained 2-fluoroethyl 3,5-bis(1H,1H,2H,2H-perfluorodecyl)benzoate 10 in an 84\% yield. The reactions of $\mathbf{1 b}$ with $(1 R, 2 R)$-1,2-diphenyl-1,2-ethandiol and 
cis-1,2-cyclododecanediol were more sluggish, and higher temperatures $\left(140{ }^{\circ} \mathrm{C}\right.$ and $160{ }^{\circ} \mathrm{C}$, respectively) were required. The resulting perfluoroalkylated benzoates of the corresponding fluorohydrins $\mathbf{1 1}$ and $\mathbf{1 2}$ were obtained in $74 \%$ and $69 \%$ yields, respectively (Table 3 ).

In order to prepare a fluorohydrin, (1R,2S)-2-fluoro-1,2-diphenylethanol, 11 was subjected to a transesterification reaction after the reaction of $\mathbf{1 b}$ with $(1 R, 2 R)$-1,2-diphenyl-1,2-ethandiol without purification. The crude 11, butanol, and a distannoxane catalyst [12] were dissolved in toluene and the mixture was stirred under reflux. After the transesterification was completed, the volatile portion was removed under reduced pressure. The residue was dissolved in the solvent system of HFE-7100 and $\mathrm{FC}-77 / \mathrm{CH}_{3} \mathrm{CN}$ (containing $5 \% \quad \mathrm{H}_{2} \mathrm{O}$ ). From the organic phase, $(1 R, 2 S)$-2-fluoro-1,2-diphenyl-1-ethanol 13 was obtained in a 55\% yield ( $>98 \%$ purity). From the fluorous phase, $\mathbf{2 b} \quad(60 \%$ based on $\mathbf{1 b})$ and butyl 3,5-bis $(1 H, 1 H, 2 H, 2 H$-perfluorodecyl)benzoate $(38 \%$ based on $1 \mathbf{b})$ were obtained (Scheme 6). 
Table 3 Fluorination of diols with $\mathbf{1 b}^{\mathrm{a}}$

Reaction cond.

a The reactions were performed using 2.4 eq of $\mathbf{1 b}$ to diol without solvent. $\operatorname{Ar}$ is 3,5-bis $(1 H, 1 H, 2 H, 2 H$-perfluorodecyl)phenyl. b Isolation yield based on diol used.

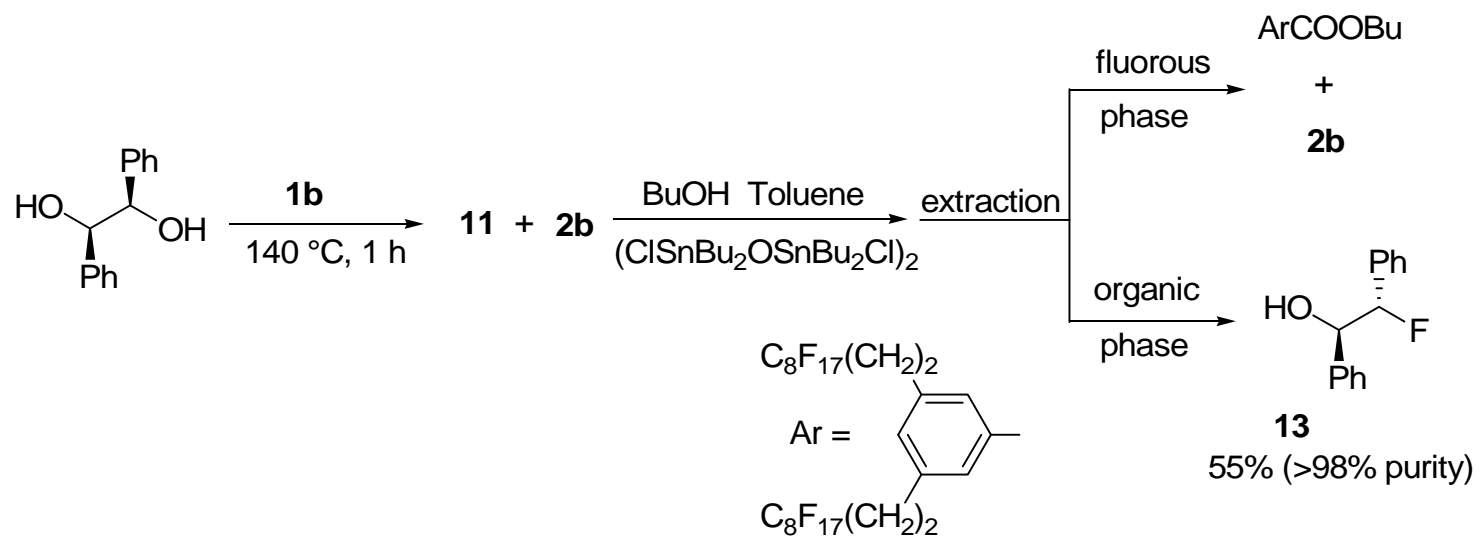

Scheme 6.

\section{Conclusion}

We prepared a novel fluorous deoxy-fluorination reagent, 
$N, N$-diethyl- $\alpha, \alpha$-difluoro-[3,5-bis $(1 H, 1 H, 2 H, 2 H$-perfluorodecyl)benzyl]amine $\mathbf{1 b}$, and used it for the fluorination of alcohols and diols. The fluorous deoxy-fluorination reagent $\mathbf{1 b}$ has comparable fluorination ability to that of DFMBA, and alcohols can be converted to the corresponding fluorinated products in good yields. After the reaction, the fluorinated products can be isolated in their pure forms by simple extraction with a fluorous/organic solvent system. The amide $\mathbf{2 b}$, generated from $\mathbf{1 b}$ after fluorination, can be recovered from the fluorous phase of the extract. The fluorous deoxy-fluorination reagent $\mathbf{1 b}$ was also applied to the fluorination of 1,2-diols and the resulting perfluoroalkylated benzoates of the fluorohydrins were converted to the fluorohydrins by the transesterification reaction. The isolation of the fluorohydrins and recovery of the fluorous reagent was achieved by extraction with a fluorous/organic solvent system.

\section{Experimental}

\subsection{General}

The melting points were measured with a Yanagimoto micro melting-point apparatus. The IR spectra were recorded using a JASCO FT/IR-410. The ${ }^{1} \mathrm{H}$ NMR (400 MHz) spectra, ${ }^{19} \mathrm{~F}$ NMR (376 MHz) spectra, and ${ }^{13} \mathrm{C}$ NMR (100 MHz) were recorded in $\mathrm{CDCl}_{3}$ on a JEOL JNM-A400II FT NMR and the chemical shift, $\delta$, is referred to TMS $\left({ }^{1} \mathrm{H},{ }^{13} \mathrm{C}\right)$ and $\mathrm{CFCl}_{3}\left({ }^{19} \mathrm{~F}\right)$, respectively. The EI-high-resolution mass spectra were measured on a JEOL JMS-700TZ. Optical rotation was measured with a Horiba High Sensitive Polarimeter. FC-77 was donated from Central Glass Co., LTD. 
PFMC, HFE-7100, and 1H,1H,2H-perfluorodec-1-ene were purchased from Wako Pure Chemical Industries, Ltd. 3,5-Diiodobenzoic acid [8], Et ${ }_{3} \mathrm{~N}-3 \mathrm{HF}$ [4], $\mathrm{ClSnBu}_{2} \mathrm{OSnBu}_{2} \mathrm{Cl}$ [12] were prepared according to the literatures.

4.2. $N, N$-diethyl- $\alpha, \alpha$-difluoro-[3,5-bis $(1 \mathrm{H}, 1 \mathrm{H}, 2 \mathrm{H}, 2 \mathrm{H}$-perfluorodecyl)benzyl]amine (1b)

A mixture of 3,5-diiodobenzoic acid [8] (3.75g, $10 \mathrm{mmol})$ and thionyl chloride $(14.3$ g, $120 \mathrm{mmol}$ ) was stirred under reflux overnight. Excess thionyl chloride was removed under reduced pressure, and $\mathrm{CH}_{2} \mathrm{Cl}_{2}(10 \mathrm{~mL})$ and $\mathrm{Et}_{2} \mathrm{NH}(3.65 \mathrm{~g}, 50 \mathrm{mmol})$ were added at $0{ }^{\circ} \mathrm{C}$ successively. After stirring at $0{ }^{\circ} \mathrm{C}$ for $30 \mathrm{~min}$, water $(50 \mathrm{~mL})$ was added, and the product was extracted with ether $(50 \mathrm{~mL} \mathrm{X} \mathrm{4).} \mathrm{The} \mathrm{separated} \mathrm{organic} \mathrm{phase} \mathrm{was} \mathrm{washed}$ with water (30 mL X 2), dried over $\mathrm{MgSO}_{4}$, and concentrated under reduced pressure. Purification by column chromatography (silica gel $/ \mathrm{CH}_{2} \mathrm{Cl}_{2}$ ) gave $N, N$-diethyl-3,5-diiodobenzamide $4 \mathbf{b}$ (3.22 g) in 75\% yield: $4 \mathbf{b}$; White solid; mp $68{ }^{\circ} \mathrm{C}$. IR (KBr): 2967, 1619, 1538, 1279, $866 \mathrm{~cm}^{-1} .{ }^{1} \mathrm{H}$ NMR $\delta 8.08(\mathrm{~s}, 1 \mathrm{H}), 7.66(\mathrm{~d}, J=1.3$ $\mathrm{Hz}, 2 \mathrm{H}), 3.50$ (brs, 2H), 3.23 (brs, 2H), 1.23 (brs, 3H), 1.12 (brs, 3H). ${ }^{13} \mathrm{C} \mathrm{NMR}$ $\delta 167.56,145.67,140.56,134.31$ (2C), 94.72 (2C), 43.32 (brs), 39.45 (brs), 14.13 (brs), 12.78 (brs). HRMS (EI): calcd. for $\mathrm{C}_{11} \mathrm{H}_{13} \mathrm{I}_{2} \mathrm{NO}\left(\mathrm{M}^{+}\right)$: 428.9087 , found: 428.9078 .

A mixture of $\mathbf{4 b}(0.215 \mathrm{~g}, 0.5 \mathrm{mmol}), 1 \mathrm{H}, 1 \mathrm{H}, 2 \mathrm{H}$-perfluorodec-1-ene $(0.49 \mathrm{~g}, 1.1$ mmol), $\mathrm{Pd}(\mathrm{OAc})_{2}(5.6 \mathrm{mg}, 0.025 \mathrm{mmol}), \mathrm{Bu}_{4} \mathrm{NBr}(0.26 \mathrm{~g}, 0.8 \mathrm{mmol})$, and $\mathrm{NaOAc}(0.11$ g, $1.3 \mathrm{mmol})$ in DMF (5 mL) was stirred under $\mathrm{N}_{2}$ atmosphere at $115{ }^{\circ} \mathrm{C}$ for 4 days. After cooling to room temperature, $\mathrm{CH}_{2} \mathrm{Cl}_{2}(30 \mathrm{~mL})$ and water $(30 \mathrm{~mL})$ were added to the reaction mixture. The separated organic phase was washed with water ( $30 \mathrm{~mL} \mathrm{X} \mathrm{2),}$ dried over $\mathrm{MgSO}_{4}$. Purification by column chromatography (silica gel/ $\mathrm{CH}_{2} \mathrm{Cl}_{2}$ :ether $=$ 
10:1) gave $N, N$-diethyl-3,5-bis( $1 H, 2 H$-perfluorodec-1-enyl)benzamide $5 \mathbf{b}$ (300 mg, $0.28 \mathrm{mmol}$ ) in $56 \%$ yield: $5 \mathbf{b}$; White solid; $\mathrm{mp} 68^{\circ} \mathrm{C}$. IR (KBr): 2992, 1617, 1241, 1214 , 1149, $979 \mathrm{~cm}^{-1} .{ }^{1} \mathrm{H}$ NMR $\delta 7.57(\mathrm{~s}, 1 \mathrm{H}), 7.51(\mathrm{~s}, 2 \mathrm{H}), 7.20(\mathrm{~d}, J=16.2 \mathrm{~Hz}, 2 \mathrm{H}), 6.29$ (dt, $J=16.0,11.8 \mathrm{~Hz}, 2 \mathrm{H}), 3.57$ (brs, 2H), 3.28 (brs, $2 \mathrm{H}), 1.28$ (brs, $3 \mathrm{H}), 1.15$ (brs, $3 \mathrm{H}) .{ }^{13} \mathrm{C}$ NMR $\delta 169.44,139.10(2 \mathrm{C}), 138.15$ (t, $J=9.1 \mathrm{~Hz}, 2 \mathrm{C}), 134.75,127.48,126.58$ (2C), 116.75 (t, $J=23.1 \mathrm{~Hz}, 2 \mathrm{C}$ ), 43.41 (brs), 39.50 (brs), 14.25 (brs), 12.87 (brs) [13]. ${ }^{19} \mathrm{~F}$ NMR $\delta-81.31(\mathrm{t}, J=9.7 \mathrm{~Hz}, 6 \mathrm{~F}),-112.01(\mathrm{dt}, J=12.2,12.2 \mathrm{~Hz}, 4 \mathrm{~F}),-121.87(\mathrm{~m}, 4 \mathrm{~F})$, $-122.43(\mathrm{~m}, 8 \mathrm{~F}),-123.24(\mathrm{~m}, 4 \mathrm{~F}),-123.61(\mathrm{~m}, 4 \mathrm{~F}),-126.64(\mathrm{~m}, 4 \mathrm{~F})$. HRMS (EI): calcd. for $\mathrm{C}_{31} \mathrm{H}_{17} \mathrm{NOF}_{34} \mathrm{Na}\left((\mathrm{M}+\mathrm{Na})^{+}\right)$: 1088.0675 , found: 1088.0670 .

A mixture of $5 \mathbf{b}(1.2 \mathrm{~g}, 1.10 \mathrm{mmol})$ and $10 \%-\mathrm{Pd} / \mathrm{C}(0.1983 \mathrm{~g})$ in AcOEt $(45 \mathrm{~mL})$ was subjected to a flask equipped with balloon $(3 \mathrm{~L})$ filled with $\mathrm{H}_{2}$. The mixture was stirred at room temperature under $\mathrm{H}_{2}$ atmosphere for $22 \mathrm{~h}$. The catalyst was removed through celite and washed with ether $(20 \mathrm{~mL} \mathrm{X} \mathrm{2).} \mathrm{The} \mathrm{filtrate} \mathrm{was} \mathrm{concentrated} \mathrm{under}$ $\begin{array}{llll}\text { reduced } & \text { pressure } & \text { give }\end{array}$ $N, N$-diethyl-3,5-bis $(1 H, 1 H, 2 H, 2 H$-perfluorodecyl)benzamide $2 \mathbf{b}(1.2 \mathrm{~g})$ in $99 \%$ yield: 2b; White solid; mp $54{ }^{\circ} \mathrm{C}$. IR (KBr): 2988, 1638, 1437, 1371, 1142, 872, 822, $664 \mathrm{~cm}^{-1}$. ${ }^{1} \mathrm{H}$ NMR $\delta 7.10$ (s, 3H), 3.55 (brs, 2H), 3.23 (brs, 2H), 2.91-2.95 (m, 4H), 2.31-2.45 (m, 4H), 1.26 (brs, 3H), 1.11 (brs, 3H). ${ }^{13} \mathrm{C}$ NMR $\delta 170.74,140.15$ (2C), 138.57, 129.06, 124.54 (2C), 121.43-105.92 (complex signals of $\mathrm{CF}_{3}$ and $\mathrm{CF}_{2}$ ), 43.26 (brs), 39.29 (brs), $32.72(\mathrm{t}, J=22.2 \mathrm{~Hz}, 2 \mathrm{C}), 26.33(\mathrm{t}, J=4.2 \mathrm{~Hz}, 2 \mathrm{C}), 14.08$ (brs), 12.79 (brs). ${ }^{19} \mathrm{~F}$ NMR $\delta$ $-81.31(\mathrm{t}, J=10.4 \mathrm{~Hz}, 6 \mathrm{~F}),-115.02(\mathrm{tt}, J=16.5,14.6 \mathrm{~Hz}, 4 \mathrm{~F}),-122.20(\mathrm{~m}, 4 \mathrm{~F})$, $-122.43(\mathrm{~m}, 8 \mathrm{~F}),-123.24(\mathrm{~m}, 4 \mathrm{~F}),-123.96(\mathrm{~m}, 4 \mathrm{~F}),-126.64(\mathrm{~m}, 4 \mathrm{~F})$. HRMS (EI): calcd. for $\mathrm{C}_{31} \mathrm{H}_{21} \mathrm{NOF}_{34} \mathrm{Na}\left((\mathrm{M}+\mathrm{Na})^{+}\right)$: 1092.0989 , found: 1092.0984 .

To a $\mathrm{CH}_{2} \mathrm{Cl}_{2}$ solution $(30 \mathrm{~mL})$ of $\mathbf{2 b}(15.9 \mathrm{~g}, 14.9 \mathrm{mmol})$ was added oxalyl 
chloride $(2.1 \mathrm{~g}, 16.4 \mathrm{mmol})$ at room temperature and the mixture was stirred under reflux for $24 \mathrm{~h}$. After cooling to $0{ }^{\circ} \mathrm{C}, \mathrm{Et}_{3} \mathrm{~N}-3 \mathrm{HF}(1.85 \mathrm{~g}, 11.5 \mathrm{mmol})$ and $\mathrm{Et}_{3} \mathrm{~N}(2.3 \mathrm{~g}$, $23 \mathrm{mmol}$ ) were added successively. The generated precipitate was separated by filtration under $\mathrm{N}_{2}$ atmosphere and washed with hexane $(30 \mathrm{~mL})$. The filtrate was concentrated under reduced pressure, and the generated solid was separated by filtration under $\mathrm{N}_{2}$ atmosphere again. The filtrate was concentrated under reduced pressure and the

distillation of the residue gave $N, N$-diethyl- $\alpha, \alpha$-difluoro-[3,5-bis( $1 H, 1 H, 2 H, 2 H$-perfluorodecyl)benzyl]amine $1 \mathbf{b}$ (13.7 g) in $84 \%$ yield, (bp $200{ }^{\circ} \mathrm{C} / 0.01 \mathrm{mmHg}$ ): $\mathbf{1 b}$; White solid (moisture sensitive). ${ }^{1} \mathrm{H}$ NMR $\delta 7.34(\mathrm{~d}, J=1.0 \mathrm{~Hz}, 2 \mathrm{H}), 7.14(\mathrm{~s}, 1 \mathrm{H}), 2.93-2.97(\mathrm{~m}, 4 \mathrm{H}), 2.87(\mathrm{q}, J=7.1 \mathrm{~Hz}$ 4H), 2.32-2.45 (m, 4H), $1.06(\mathrm{t}, J=7.1 \mathrm{~Hz}, 6 \mathrm{H}) .{ }^{19} \mathrm{~F}$ NMR $\delta-73.92(\mathrm{~s}, 2 \mathrm{~F}),-81.31(\mathrm{~s}$, 6F), -114.93 (s, 4F), -122.01 (s, 4F), -122.34 (s, 8F), -123.15 (s, 4F), -123.81 (s, 4F), $-128.59(\mathrm{~s}, 4 \mathrm{~F})$.

\subsection{Fluorination of alcohols}

\subsubsection{1-Fluorododecane}

1-Dodecanol (186 mg, $1 \mathrm{mmol}), \mathbf{1 b}(1.34 \mathrm{~g}, 1.2 \mathrm{mmol})$, and heptane (1 mL) were introduced into a reaction vessel made of Teflon PFA with a tight screw cap, and the mixture was stirred at $98{ }^{\circ} \mathrm{C}$ for $3 \mathrm{~h}$. After cooling to room temperature, the mixture was concentrated under reduced pressure. The residue was dissolved in a mixture of PFMC (10 mL) and toluene $(5 \mathrm{~mL})$, and separated toluene phase was washed with PFMC (10 mL) twice. Concentration of toluene phase gave pure 1-fluorododecane (141 
$\mathrm{mg}$ ) in $75 \%$ yield. On the other hand, GC analysis showed that the PFMC phase contains 2b, 1-fluorododecane, and dodecyl 3,5-bis $(1 H, 1 H, 2 H, 2 H$-perfluorodecyl)benzoate 8 in a ratio of 87:7:6.

1-Fluorododecane [3b]; IR (neat): 2925, 2855, 1466, 1389, 1050, $1010 \mathrm{~cm}^{-1} .{ }^{1} \mathrm{H}$ NMR $\delta$ $4.44(\mathrm{dt}, J=47.3,6.3 \mathrm{~Hz}, 2 \mathrm{H}), 1.74-1.64(\mathrm{~m}, 2 \mathrm{H}), 1.39-1.26(\mathrm{~m}, 18 \mathrm{H}), 0.88(\mathrm{t}, J=6.7$ Hz, 3H). ${ }^{13} \mathrm{C}$ NMR $\delta$ 14.07, 22.71, 25.19 (d, $J=5.0$ Hz), 29.29, 29.39, 29.56, 29.60, 29.67, 29.69, $30.46(\mathrm{~d}, J=19.0 \mathrm{~Hz}), 31.96,84.11(\mathrm{~d}, J=163.8 \mathrm{~Hz}) .{ }^{19} \mathrm{~F}$ NMR $\delta$ -218.36 to $-218.75(1 \mathrm{~F}, \mathrm{~m})$

\subsubsection{Butyl 5-fluoropentanoate (7)}

The reaction was carried out as in the case of 3.3.1 using butyl 5-hydroxypentanoate 6 (174 mg, $1 \mathrm{mmol}$ ) instead of 1-dodecanol. After the reaction, volatile part was removed under reduced pressure, and the residue was dissolved in a mixture of FC-77 $(10 \mathrm{~mL}), \mathrm{HFE}-7100(10 \mathrm{~mL})$, and $\mathrm{CH}_{3} \mathrm{CN}$ (containing $\left.5 \% \mathrm{H}_{2} \mathrm{O}\right)(10 \mathrm{~mL})$. The separated $\mathrm{CH}_{3} \mathrm{CN}$ phase was concentrated under reduced pressure to gave pure 7 (127 $\mathrm{mg}$ ) in $72 \%$ yield. GC analysis showed that the fluorous phase contained $\mathbf{2 b}, \mathbf{7}$, and 5-butoxycarbonylbutyl 3,5-bis $(1 \mathrm{H}, 1 \mathrm{H}, 2 \mathrm{H}, 2 \mathrm{H}$-perfluorodecyl)benzoate 9 in a ratio of $95: 3: 2$.

Butyl 5-fluoropentanoate 7 [3b], IR (neat): 2962, 1736, $1172 \mathrm{~cm}^{-1} .{ }^{1} \mathrm{H}$ NMR $\delta 4.46$ (dt, $J$ $=47.6,5.6 \mathrm{~Hz}, 2 \mathrm{H}), 4.08(\mathrm{t}, J=6.6 \mathrm{~Hz}, 2 \mathrm{H}), 2.36(\mathrm{t}, J=6.3 \mathrm{~Hz}, 2 \mathrm{H}), 1.80-1.71(\mathrm{~m}$, 4H), 1.65-1.56 (m, 2H), 1.43-1.33 (m, 2H), $0.94(\mathrm{t}, J=7.4 \mathrm{~Hz}, 3 \mathrm{H}) .{ }^{13} \mathrm{C}$ NMR $\delta 13.58$, 19.04, 20.77 (d, $J=5.0 \mathrm{~Hz}), 29.69$ (d, $J=19.9 \mathrm{~Hz}), 30.58,33.64,64.14,83.47$ (d, $J=$ 165.4 Hz), 173.25. ${ }^{19}$ F NMR $\delta-219.25$ to $-219.66(\mathrm{~m}, 1 \mathrm{~F})$. 


\subsection{Fluorination of diols}

\subsubsection{2-Fluoroethyl 3,5-bis(1H,1H,2H,2H-perfluorodecyl)benzoate (10)}

Ethylene glycol (62 mg, $1 \mathrm{mmol})$ and $\mathbf{1 b}(2.674 \mathrm{~g}, 2.4 \mathrm{mmol})$ were introduced into a reaction vessel made of Teflon ${ }^{\mathrm{TM}}$ PFA with a tight screw cap and the mixture was stirred at $95{ }^{\circ} \mathrm{C}$ for $1 \mathrm{~h}$. The reaction mixture was poured into aqueous $5 \% \mathrm{NaOH}(20 \mathrm{~mL})$ and separated aqueous layer was extracted with $\mathrm{CH}_{2} \mathrm{Cl}_{2}(20 \mathrm{~mL} \mathrm{X} 3)$. The combined organic layer was dried over $\mathrm{MgSO}_{4}$ and concentrated uder reduced pressure. Purification by column chromatography (silica gel $/ \mathrm{CH}_{2} \mathrm{Cl}_{2}-\mathrm{Et}_{2} \mathrm{O}$ ) gave $\mathbf{1 0}(890 \mathrm{mg}$ ) in $84 \%$ yield. White solid; mp $62.5-63{ }^{\circ} \mathrm{C}$, IR (KBr): $1725,1454,1203 \mathrm{~cm}^{-1} .{ }^{1} \mathrm{H}$ NMR $\delta$ $7.82(\mathrm{~s}, 2 \mathrm{H}), 7.30(\mathrm{~s}, 1 \mathrm{H}), 4.76(\mathrm{dt}, J=47.4,3.7 \mathrm{~Hz}, 2 \mathrm{H}), 4.76(\mathrm{dt}, J=28.8,4.2 \mathrm{~Hz}, 2 \mathrm{H})$, 2.94-3.02 (m, 4H), 2.31-2.48 (m, 4H). ${ }^{13} \mathrm{C}$ NMR $\delta 165.94,140.22$ (2C), 133.34, 130.78, 128.03 (2C), 81.35 (d, $J=170.6 \mathrm{~Hz}), 64.08$ (d, $J=20.2 \mathrm{~Hz}), 32.73$ (t, $J=22.7 \mathrm{~Hz}, 2 \mathrm{C})$, $26.26(\mathrm{t}, J=4.1 \mathrm{~Hz}, 2 \mathrm{C})[13] .{ }^{19} \mathrm{~F}$ NMR $\delta-81.34(\mathrm{t}, J=9.8 \mathrm{~Hz}, 6 \mathrm{~F}),-115.10$ (quint, $J$ $=14.0 \mathrm{~Hz}, 4 \mathrm{~F}),-122.25(\mathrm{~s}, 4 \mathrm{~F}),-122.50(\mathrm{~s}, 8 \mathrm{~F}),-123.30(\mathrm{~s}, 4 \mathrm{~F}),-123.99(\mathrm{~s}, 4 \mathrm{~F})$, $-126.70(\mathrm{~s}, 4 \mathrm{~F}),-225.03(\mathrm{tt}, J=47.6,28.7 \mathrm{~Hz}, 1 \mathrm{~F})$. HRMS (ESI): calcd. for $\mathrm{C}_{29} \mathrm{H}_{16} \mathrm{O}_{2} \mathrm{~F}_{35}\left(\mathrm{M}^{+}+\mathrm{H}\right):$ 1061.0592, found: 1061.0609.

\subsection{2. (1R,2S)-2-Fluoro-1,2-diphenylethyl}

3,5-bis(1H,1H,2H,2H-perfluorodecyl)benzoate (11)

White solid; $\operatorname{mp} 81-82{ }^{\circ} \mathrm{C},[\alpha]_{\mathrm{D}}{ }^{21}=+23.1\left(\mathrm{c}=1.00, \mathrm{CHCl}_{3}\right)$, IR $(\mathrm{KBr}): 1712$, 
1456, $1148 \mathrm{~cm}^{-1} .{ }^{1} \mathrm{H}$ NMR $\delta 7.88(\mathrm{~s}, 2 \mathrm{H}), 7.15-7.35(\mathrm{~m}, 11 \mathrm{H}), 6.29(\mathrm{dd}, J=17.6,4.0$ $\mathrm{Hz}, 1 \mathrm{H}), 5.86(\mathrm{dd}, J=46.2,4.1 \mathrm{~Hz}, 1 \mathrm{H}), 2.90-3.01(\mathrm{~m}, 4 \mathrm{H}), 2.29-2.39(\mathrm{~m}, 4 \mathrm{H}) .{ }^{13} \mathrm{C}$ NMR $\delta 164.86,140.24(2 \mathrm{C}), 135.41(\mathrm{~d}, J=20.2 \mathrm{~Hz}), 134.75(\mathrm{~d}, J=3.4 \mathrm{~Hz}), 133.34$, 130.96, 128.85, 128.68, 128.24 (2C), 128.03 (2C), 128.00 (2C), 127.73 (2C), 126.55 (d, $J=7.3 \mathrm{~Hz}, 2 \mathrm{C}), 122.00-108.00$ (complex signals of $\mathrm{CF}_{3}$ and $\left.\mathrm{CF}_{2}\right), 94.51(\mathrm{~d}, J=180.3$ $\mathrm{Hz}), 77.99$ (d, $J=25.7 \mathrm{~Hz}), 32.70(\mathrm{t}, J=22.1 \mathrm{~Hz}, 2 \mathrm{C}), 26.26(\mathrm{t}, J=3.9 \mathrm{~Hz}, 2 \mathrm{C}) .{ }^{19} \mathrm{~F}$ NMR $\delta-81.33(\mathrm{t}, J=9.8 \mathrm{~Hz}, 6 \mathrm{~F}),-115.06$ (quint, $J=14.0 \mathrm{~Hz}, 4 \mathrm{~F}),-122.23(\mathrm{~s}, 4 \mathrm{~F})$, $-122.48(\mathrm{~s}, 8 \mathrm{~F}),-123.29(\mathrm{~s}, 4 \mathrm{~F}),-123.97(\mathrm{~s}, 4 \mathrm{~F}),-126.69(\mathrm{~s}, 4 \mathrm{~F}),-187.70(\mathrm{dd}, J=46.4$, 17.7 Hz, 1F). HRMS (ESI): calcd. for $\mathrm{C}_{41} \mathrm{H}_{23} \mathrm{O}_{2} \mathrm{~F}_{35} \mathrm{Na}\left((\mathrm{M}+\mathrm{Na})^{+}\right)$: 1235.1033 , found: 1235.1018.

4.4.3. trans-2-Fluorocyclododecyl 3,5-bis $(1 \mathrm{H}, 1 \mathrm{H}, 2 \mathrm{H}, 2 \mathrm{H}$-perfluorodecyl)benzoate (12)

White solid; $\mathrm{mp} 85.5-86{ }^{\circ} \mathrm{C}$, IR (KBr): $1716,1469,1149 \mathrm{~cm}^{-1} .{ }^{1} \mathrm{H}$ NMR $\delta 7.81(\mathrm{~s}$, 2H) $)_{\text {. }} 7.27(\mathrm{~s}, 1 \mathrm{H}), 5.44-5.55(\mathrm{~m}, 1 \mathrm{H}), 4.85(\mathrm{ddt}, J=48.6,8.0,4.3 \mathrm{~Hz}, 1 \mathrm{H}), 2.85-3.07$ (m, 4H), 2.27-2.50 (m, 4H), 1.17-1.99 (m, 20H). ${ }^{13} \mathrm{C}$ NMR $\delta 165.87,140.08$ (2C) 132.96, 131.46, 127.99 (2C), 91.78 (d, $J=175.5 \mathrm{~Hz}), 72.97$ (d, $J=17.0 \mathrm{~Hz}), \quad 32.76$ (t, $J=22.3 \mathrm{~Hz}, 2 \mathrm{C}), 28.09(\mathrm{~d}, J=21.2 \mathrm{~Hz}), 27.31(\mathrm{~d}, J=5.0 \mathrm{~Hz}), 26.26(\mathrm{t}, J=3.5 \mathrm{~Hz}, 2 \mathrm{C})$, 23.87, 23.78, 23.72, 23.68, 22.89, 22.82, 20.65, $20.44(\mathrm{~d}, J=3.5 \mathrm{~Hz})[13] .{ }^{19} \mathrm{~F}$ NMR $\delta$ $-81.34(\mathrm{t}, J=9.7 \mathrm{~Hz}, 6 \mathrm{~F}),-115.11$ (quint, $J=15.3 \mathrm{~Hz}, 4 \mathrm{~F}),-122.25(\mathrm{~s}, 4 \mathrm{~F}),-122.49$ (s, 8F), $-123.29(\mathrm{~s}, 4 \mathrm{~F}),-123.98(\mathrm{~s}, 4 \mathrm{~F}),-126.69(\mathrm{~s}, 4 \mathrm{~F}),-193.23$ to $-193.62(\mathrm{~m}, 1 \mathrm{~F})$. HRMS (ESI): calcd. for $\mathrm{C}_{39} \mathrm{H}_{33} \mathrm{O}_{2} \mathrm{~F}_{35} \mathrm{Na}\left((\mathrm{M}+\mathrm{Na})^{+}\right)$: 1221.1819 found: 1221.1820 .

4.4.4. (1R,2S)-2-Fluoro-1,2-diphenylethanol (13) 
A mixture of $\mathbf{1 b}(1.337 \mathrm{~g}, 1.2 \mathrm{mmol})$ and $(1 R, 2 R)$-1,2-diphenyl-1,2-ethandiol (107 mg, $0.5 \mathrm{mmol}$ ) was stirred at $140{ }^{\circ} \mathrm{C}$ for $1 \mathrm{~h}$. The reaction mixture was cooled to room temperature and $5 \%$ aq $\mathrm{NaOH}(20 \mathrm{~mL})$ was added. The mixture was stirred for $30 \mathrm{~min}$ and HFE-7100 (20 mL) was added. The separated aqueous layer was extracted with HFE-7100 (10 mL X 2). The combined HFE-7100 layer was dried over $\mathrm{MgSO}_{4}$ and concentrated under reduced pressure. The residue was dissolved in toluene $(15 \mathrm{~mL})$ with butanol (1.113 g, $15 \mathrm{mmol})$ and $\mathrm{ClSnBu}_{2} \mathrm{OSnBu}_{2} \mathrm{Cl}(553 \mathrm{mg}, 1 \mathrm{mmol})$, and the mixture was stirred under reflux for 8 days. The mixture was cooled to $0{ }^{\circ} \mathrm{C}$ and solid part was removed by filtration. The filtrate was concentrated under reduced pressure and the residue was dissolved in a mixture of FC-77 $(20 \mathrm{~mL})$, HFE-7100 $(20 \mathrm{~mL})$, and $\mathrm{CH}_{3} \mathrm{CN}\left(5 \%\right.$ of $\left.\mathrm{H}_{2} \mathrm{O}\right)(20 \mathrm{~mL})$. The separated $\mathrm{CH}_{3} \mathrm{CN}$ layer was washed with a mixture of FC-77 (20 mL) and HFE-7100 (20 mL), once, and concentrated under reduced pressure to give $\mathbf{1 3}(60 \mathrm{mg})$ in $55 \%$ yield. ${ }^{19} \mathrm{~F}$ NMR analysis of the fluorous layer showed the formation of amide $2 \mathbf{b}(60 \%)$ and 8 (38\%); 13; White solid; mp $98{ }^{\circ} \mathrm{C}$ (lit. $\left.{ }^{[14]} 99{ }^{\circ} \mathrm{C}\right) .[\alpha]_{\mathrm{D}}{ }^{22.1}=+19.7(\mathrm{c}=1.00, \mathrm{MeOH}) . \mathrm{IR}:(\mathrm{KBr}) 3578,3033,2880,1452$, 1050, 965, $706 \mathrm{~cm}^{-1} .{ }^{1} \mathrm{H}$ NMR $\delta 7.19-7.39(\mathrm{~m}, 10 \mathrm{H}), 5.52(\mathrm{dd}, J=45.8,5.6 \mathrm{~Hz}, 1 \mathrm{H})$, $5.01(\mathrm{ddd}, J=12.1,5.5,4.0 \mathrm{~Hz}, 1 \mathrm{H}), 2.11(\mathrm{~d}, J=3.9 \mathrm{~Hz} 1 \mathrm{H}) .{ }^{13} \mathrm{C}$ NMR $\delta 138.82(\mathrm{~d}, J$ $=3.1 \mathrm{~Hz}), 135.95(\mathrm{~d}, J=19.9 \mathrm{~Hz}), 128.79(\mathrm{~d}, J=1.7 \mathrm{~Hz}), 128.25(2 \mathrm{C}), 128.19$ (2C), 127.00 (2C), 126.98 (2C), $126.78(\mathrm{~d}, J=7.2 \mathrm{~Hz}), 96.21(J=177.8 \mathrm{~Hz}), 76.31(\mathrm{~d}, J=$ $27.2 \mathrm{~Hz}) .{ }^{19} \mathrm{~F}$ NMR $\delta-183.83(\mathrm{dd}, J=45.8,12.2 \mathrm{~Hz}, 1 \mathrm{~F})$.

\section{References}

[1] (a) D. P. Curran, Angew. Chem. Int. Ed. 37 (1998) 1174-1196; (b) A. P. Dobbs, M. R. Kimberley, J. Fluorine Chem. 118 (2002) 3-17; (c) W. Zhang, Chem. Rev. 104 
(2004) 253-25561; (d) D. P. Curran, I. T. Horváth, J. A. Handbook of Fluorous Chemistry, Gladysz, (Eds),Wiley-VCH, Weinheim, 2004.

[2] (a) C.-L. J. Wang, Fluorination by Sulfur Tetrafluoride, in: Organic Reactions, vol. 34, Willey, New York, 1985, pp. 319-412. (b) M. Hudlicky, Fluorination with Diethylaminosulfur Trifluoride and Related Aminofulorosulfuranes, in: Organic Reactions, vol 35, Willey, New York, 1988, pp. 513-637. (c) R. P. Singh, J. M. Shreeve, Synthesis, (2002) 2561-2578.

[3] (a) S. Kobayashi, A. Yoneda, T. Fukuhara, S. Hara, Tetrahedron Lett. 45 (2004) 1287-1289. (b) S. Kobayashi, A.Yoneda, T. Fukuhara, S. Hara, Tetrahedron 60 (2004) 6923-6930.

[4] T. Furuya, T. Fukuhara, S. Hara, J. Fluorine Chem. 126 (2005) 721-725.

[5] A. Yoneda, T. Fukuhara, S. Hara, Chem. Commun. (2005) 3589-3590.

[6] T. Nomoto, T. Fukuhara, S. Hara, Synlett (2006) 1744-1746.

[7] H.-W. Yu, Y. Nakano, T. Fukuhara, S. Hara, J. Fluorine Chem. 126 (2005) 962-966.

[8] A. Endres, G. Maas, Tetrahedron 58 (2002) 3999-4005.

[9] (a) S. Darses, M. Pucheault, J.-P. Genêt, Eur. J. Org. Chem. (2001) 1121-1128. (b) W. Chen, L. Xu, J. Xiao, Tetrahedron Lett. 42 (2001) 4257-4278.

[10] T. Fukuhara, C. Hasegawa, S. Hara, Synthesis (2007) 1528-1534.

[11] From partition data in Table 2, contamination of fluorododecane in the fluorous phase is not acceptable. In order to remove $\mathbf{2 b}$ from the organic phase completely and to obtain the pure product, the separated organic phase was washed with fluorous solvent again, and that extra operation must cause the contamination of fluorododecane in fluorous phase.

[12] (a) J. Otera, T. Yano, A. Kawabata, H. Nozaki, Tetrahedron Lett. 27 (1986) 
2383-2389. (b) A. Orita, K. Sakamoto, Y. Hamada, A. Mitsutome, J. Otera, Tetrahedron 55 (1999) 2899-2910.

[13] Signals due to carbons of the fluorocarbon chains were too weak to be assigned.

[14] S. Rozen, O. Lerman, J. Org. Chem. 45 (1980) 672-678. 